\title{
Aflatoxin $\mathrm{B}_{1}$ and Tobacco Products
}

by

E.D. Massey

British American Tobacco, $R \& D$ Centre, Regents Park Road, Southampton, UK

\section{SUMMARY}

The potential for aflatoxin $\mathrm{B}_{1}$ contamination of tobaccos and its subsequent transfer to smoke has been raised. This paper examines published work relevant to this issue and concludes that aflatoxin $\mathrm{B}_{1}$ is not a contamination issue on tobaccos and, even if present, would decompose in the burning cigarette and would not transfer to smoke. [Beitr. Tabakforsch. Int. 19 (2000) 167-168]

\section{ZUSAMMENFASSUNG}

Es wurde die Frage nach einer möglichen Verunreinigung des Tabaks durch Aflatoxin $\mathrm{B}_{1}$ und den nachfolgenden Übergang in den Tabakrauch aufgeworfen. Diese Arbeit untersucht die Literatur zu diesem Thema und kommt zu dem Schluß, dass Aflatoxin $B_{1}$ kein Verunreinigungsproblem für Tabak darstellt und, auch wenn es vorhanden wäre, in der brennenden Cigarette Zersetzungsprozesse stattfänden und Aflatoxin $B_{1}$ nicht in den Rauch übergehen würde. [Beitr. Tabakforsch. Int. 19 (2000) 167-168]

\section{RESUME}

La possibilité d'une contamination du tabac par l'aflatoxine $B_{1}$ et son transfert ultérieur vers la fumée est discuté. Cette étude examine la littérature relative à ce sujet et aboutit à la conclusion que l'aflatoxine $\mathrm{B}_{1}$ n'est pas un sujet de contamination du tabac et, même si l'aflatoxine $B_{1}$ était présente, une dégradation aurait lieu dans la cigarette au cours de la combustion et l'aflatoxine $B_{1}$ ne serait pas transférée vers la fumée. [Beitr. Tabakforsch. Int. 19 (2000) 167-168]

\section{INTRODUCTION}

It has recently been suggested that the carcinogenic fungal metabolite of Aspergillusflavus, aflatoxin $\mathrm{B}_{1}$, is present on tobaccos and will transfer to mainstream and sidestream smoke and that smokers, or people in the presence of smoke, will inhale aflatoxin $\mathrm{B}_{1}(1)$. This paper examines published work relevant to this assertion and concludes that aflatoxin $B_{1}$ is not a contamination issue on tobaccos and, even if present on tobaccos, would not transfer to smoke.

\section{AVAILABLE INFORMATION AND CONCLUSIONS}

Work concerning aflatoxin $\mathrm{B}_{1}$ on tobacco has been carried out by TSO and SOROKIN of the US Department of Agriculture in a range of experiments (2). They assayed mouldy and sound tobaccos for their aflatoxin $B_{1}$ content and none was detected.

In addition, cigarettes were made from tobaccos spiked with either $500 \mathrm{ppb}$ or $5000 \mathrm{ppb}$ aflatoxin $\mathrm{B}_{1}$. Using a method with a detection limit of $0.3 \mathrm{ppb}$, no aflatoxin $\mathrm{B}_{1}$ was detected in the smoke condensate (2). These data and the issue of aflatoxin $B_{1}$ were subsequently discussed in the 1979 report of the US Surgeon General (3). The report states

Aflatoxins have been reported to occur in many commodities, but its presence in leaf tobacco has not been positively confirmed, although $A$. flavus was known to be present.

The report goes on to conclude

Pure aflatoxin $\mathrm{B}_{1}$ added to cigarettes was not recovered in the smoke condensate, indicating that aflatoxin $\mathrm{B}_{1}$, even if present, was changed or decomposed during the smoking process.

The Surgeon General has not seen it necessary to address the issue subsequently.

In a separate piece of work at the Northwest University Medical School in Chicago, cigarettes were spiked with either 100 or $300 \mu \mathrm{g}$ of aflatoxin $B_{1}$ and smoked (4). 
Methodology with a detection limit of $0.01 \mu \mathrm{g}$ demonstrated there was no detectable aflatoxin $B_{1}$ in either the cigarette butts, the ash, the smoke condensate or smoke vapour phase trapped in solvent. This study also found that thermal degradation of aflatoxin $\mathrm{B}_{1}$ occurs at $264^{\circ} \mathrm{C}$, only slightly above its melting point of $263^{\circ} \mathrm{C}$. Thus it is highly unlikely that the aflatoxin $\mathrm{B}_{1}$ would transfer undecomposed to smoke and this, as outlined above, has been effectively confirmed by TSO and SOROKIN and KAMINSKI $e t$ al. in their spiking experiments $(2,4)$.

One positive report of aflatoxin $\mathrm{B}_{1}$ on tobacco originates from Egypt (5). However, this group also injected cigarettes with 10,20 and $50 \mu \mathrm{g}$ aflatoxin $\mathrm{B}_{1}$, and they confirm the previous reports of no detectable aflatoxin $B_{1}$ in the smoke. After smoking, aflatoxin $\mathrm{B}_{1}$ was found in the cigarette filters. However, the spiking doses of aflatoxin $B_{1}$ were injected into the cigarettes in $1 \mathrm{~mL}$ of chloroform, which will contaminate the filter and would transfer aflatoxin $\mathrm{B}_{1}$ to the filter by solvent transfer rather than via the smoke.

The paper speculating that aflatoxin $B_{1}$ is present in smoke, cited tobacco industry documents which indicate $100 \%$ transfer of aflatoxin $\mathrm{B}_{1}$ to smoke during tobacco combustion (1). However, subsequent follow up documents from the cited company, report that there is no substance to this claim (6).

Support for the hypothesis of aflatoxin $\mathrm{B}_{1}$ transfer to mainstream smoke and environmental tobacco smoke was provided by the assertion that the decomposition temperature of aflatoxin $\mathrm{B}_{1}$, given as $269^{\circ} \mathrm{C}$, is above the combustion temperature of an idling cigarette (1). On the contrary, the degradation temperature of aflatoxin $\mathrm{B}_{1}$ of $264^{\circ} \mathrm{C}$ is well exceeded during the smoking and smouldering of a cigarette (4). The gas and solid phase temperature in a smouldering cigarette are almost $800^{\circ} \mathrm{C}$ in the centre of the burning zone and over $500^{\circ} \mathrm{C}$ at the edge of the burning zone (10). During a puff, temperatures of over $900{ }^{\circ} \mathrm{C}$ occur $(7-10)$. The sidestream products (which go on to become the major contributor to environmental tobacco smoke) leave the burning zone predominantly during the smoulder period between puffs. The sidestream gases (carbon monoxide, carbon dioxide, hydrogen and water) are formed in the interior of the burning zone and diffuse out with an initial temperature in excess of $350^{\circ} \mathrm{C}$. The sidestream particulate phase components are formed in a pyrolysis/ distillation zone immediately behind the burning zone, here the temperatures are up to $600^{\circ} \mathrm{C}$. They diffuse outwards through the partially degraded cigarette paper and become visible as smoke as the sidestream smoke temperature falls below about $150^{\circ} \mathrm{C}(10-12)$.

Acknowledgement: I would like to thank Dr Richard Baker for his advice on combustion conditions in a burning cigarette and for his review of the manuscript.

\section{REFERENCES}

1. Lane K.S.: Aflatoxin, tobacco, ammonia and the p53 tumour-suppressor gene: cancer's missing link? http://oncology.medscape.com/Medscape/ General Medicine/journal/1999/v01.n08/mgm0830.lane/ mgm0830.lane .html

2. Tso, T.C., and T. Sorokin: Examination of aflatoxin $\mathrm{B}_{1}$ in leaf tobacco and in cigarette smoke condensate; Beitr. Tabakforsch.. 4 (1967) 18-20.

3. U.S. Department of Health, Education, and Welfare: Smoking and health; A report of the Surgeon General, U.S. Office on Smoking and Health, DHEW Publication no. (PHS) 79-50066, 1979, pp.14-22.

4. Kaminski, E.J., J.C. Lazanas, L.L. Wolfson, O.E. Fancher, and J.C. Calandra: Fate of aflatoxins in cigarette tobacco; Beitr. Tabakforsch. 5 (1970) 189-192.

5. El-Maghraby, O.M.O., and M.A. Abdel-Sater: Mycoflora and natural occurrence of mycotoxins in tobacco from cigarettes in Egypt; Zentrabl. Mikrobiol. 148 (1993) 253-264.

6. R.J.Reynolds letter: Letter from RJR in-house legal council to outside legal council for tobacco companies conveying legal advice concerning special account No. 4 project dated July 25; 1968, Bates no. 50186-8750.

7. Egerton, A., K. Guyan, and F.J. Weinberg: The mechanism of smouldering in cigarettes; Combust. Flame. 7 (1963) 63-78.

8. Baker, R.R.: Temperature distribution inside a burning cigarette; Nature 247 (1974) 405-406.

9. Baker, R.R.: Temperature variation within a cigarette combustion coal during the smoking cycle; High Temp. Sci. 7 (1975) 236-247.

10. Baker, R.R.: Smoke chemistry; in: Tobacco: production, chemistry and technology, edited by D.L. Davis and M.T. Nielsen, Blackwell Science Ltd, Oxford, 1999, pp. 398-439.

11. Baker, R.R., and C.J. Proctor: The origins and properties of environmental tobacco smoke; Env. Int. 16 (1990) 231-245.

12. Baker, R.R.: Variation of sidestream gas formation during the smoke cycle; Beitr. Tabakforsch. Int. 11 (1982) 181-193.

\section{Address for correspondence:}

Eian D Massey

British American Tobacco

$R \& D$ Centre, Regents Park Road

UK-Southampton SO15 8TL

Telephone: (+44) 2380-777155

Fax: $\quad$ (+44) 2380-793480

Email:_eian_massey@britamtob.com 